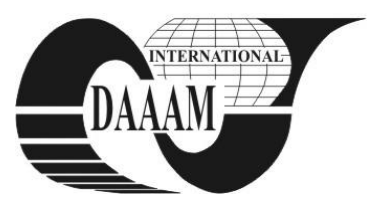

Annals of DAAAM for 2012 \& Proceedings of the 23rd International DAAAM Symposium, Volume 23, No.1, ISSN 2304-1382 ISBN 978-3-901509-91-9, CDROM version, Ed. B. Katalinic, Published by DAAAM International, Vienna, Austria, EU, 2012 Make Harmony between Technology and Nature, and Your Mind will Fly Free as a Bird Annals \& Proceedings of DAAAM International 2012

\title{
KPI OPTIMIZATION FOR PRODUCT DEVELOPMENT PROCESS
}

\author{
DURKACOVA, M[ichaela]; LAVIN, J[aak] \& KARJUST, K[risto]
}

\begin{abstract}
Companies operating in a fast changing business climate must pay careful attention to financial and nonfinancial performance indicators, which can be determined by the Balanced Scorecard. This paper analyses the relationship between four Balanced Scorecard perspectives, important success factors and performance indicators for the product development process with the help of a case study in real company.
\end{abstract}

Keywords: performance management, balanced scorecard, key performance indicators, critical success factors

\section{INTRODUCTION}

Traditional performance measurement methodologies focus only on cost and benefit factors and hence, lack the ability to evaluate supply chains. Balanced Scorecard, eliminating this setback, build a balance between financial and non-financial, organizational and nonorganizational performance measures, and hence, suggests a more thorough evaluation methodology. This paper aims to measure and evaluate the performance of a given company, depending on the components of BSC four perspectives, strategic goals, critical success criteria and key performance indicators. A generic BSC structure and a case study are included in the paper to demonstrate the steps of the performance evaluation process. We focus on the real product development process, key performance indicators of internal business processes perspective and core competencies of employees.

\section{PERFORMANCE MANAGEMENT}

Businesses have become more and more widespread and diverse and have aimed their strategies for enhancing the long term growth, success and performance.

As a product development process is more complex, the availability and exchange of information is more critical to the efficiency of the business. To improve their ability to innovate, bring products to market faster and reduce manufacturing bottlenecks, the manufacturers have been improving their product development and management abilities. In the recent years has been seen growing investments in the area of product lifecycle management and different enterprise resource planning systems (including adaptive web-based quotation modules and optimal resource planning modules) [1,2].

The correlation of planning, production, sourcing, distribution, finance and work force information in near real time is a proven way to empower both management and staff, to reduce errors and increase production efficiency [3]. Companies are often talking about different ways of business performance management.

\subsection{The most popular performance management tools}

The current environment of globalization and economic turbulence has increased the challenges executives face and, therefore, here is the need to find the right tools to meet these challenges. We focused on 25 of the most popular performance management tools and techniques which have become a common part of executives' lives (according to a multi-year research project launched since 1993 by consulting firm Bain \& Company. In 2011 they received 1230 completed surveys from a broad range of international executives that represent a various industries and company sizes) [4].

Top 10 performance management tools have varied over time. As company's needs may have changed, managers might stop using or start to use a tool for many reasons. Benchmarking, Strategic Planning, Mission and Vision Statements were for the third time the satisfaction and usage leaders in 2010. Top ten management tools in 2010 were projected to have higher usage levels in 2011 as shows Figure $1[4,5]$.

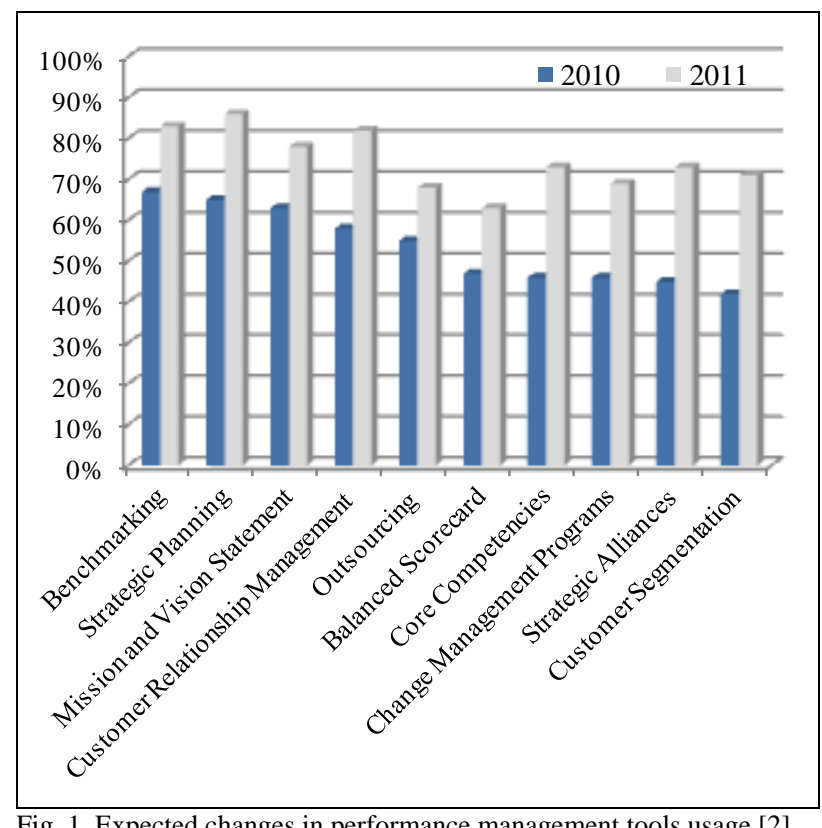

The pursuit of growth is also leading executives to try new tools like social media programs - use online communities like Facebook, micro-blogging sites such as Twitter and corporate websites to try to strengthen bonds and grow loyalty with employees, customers and partners. While only $29 \%$ of all respondents say they used social media in 2010, usage is expected to surge to $56 \%$ in 2011 . But there is uncertainty of measuring the effectiveness of this tool [3]. 
To be effective, performance measurement system have to be accurate, timely, actionable and a strong indicator of achieving the over-arching business objectives.

\subsection{Balanced Scorecard}

Companies are trying to bridge the gap between strategy and performance of processes with the aim to optimize their performance. Probably the best known, the most sophisticated and in terms of implementation the most successful performance measurement system is called Balanced Scorecard (BSC). It was found to be the sixth most widely used management tools across the globe which also had one of the highest overall satisfaction ratings. It took the sixth position $[6,7]$.

This concept translates strategy in terms of objectives, success factors and performance indicators in the four perspectives - financial, customer, learning and growth and internal processes. Environmental and social aspects can also be subsumed under the four existing BSC perspectives [8].

Elements that are vital for a strategy to be successful are Critical Success Factors (CSFs). Once you identify the CSFs for each perspective, it is important to identify the Key Performance Indicators (KPIs) [9]. Therefore, to become a successful business the company should measure the performance of the CSFs of all four perspectives using the KPIs.

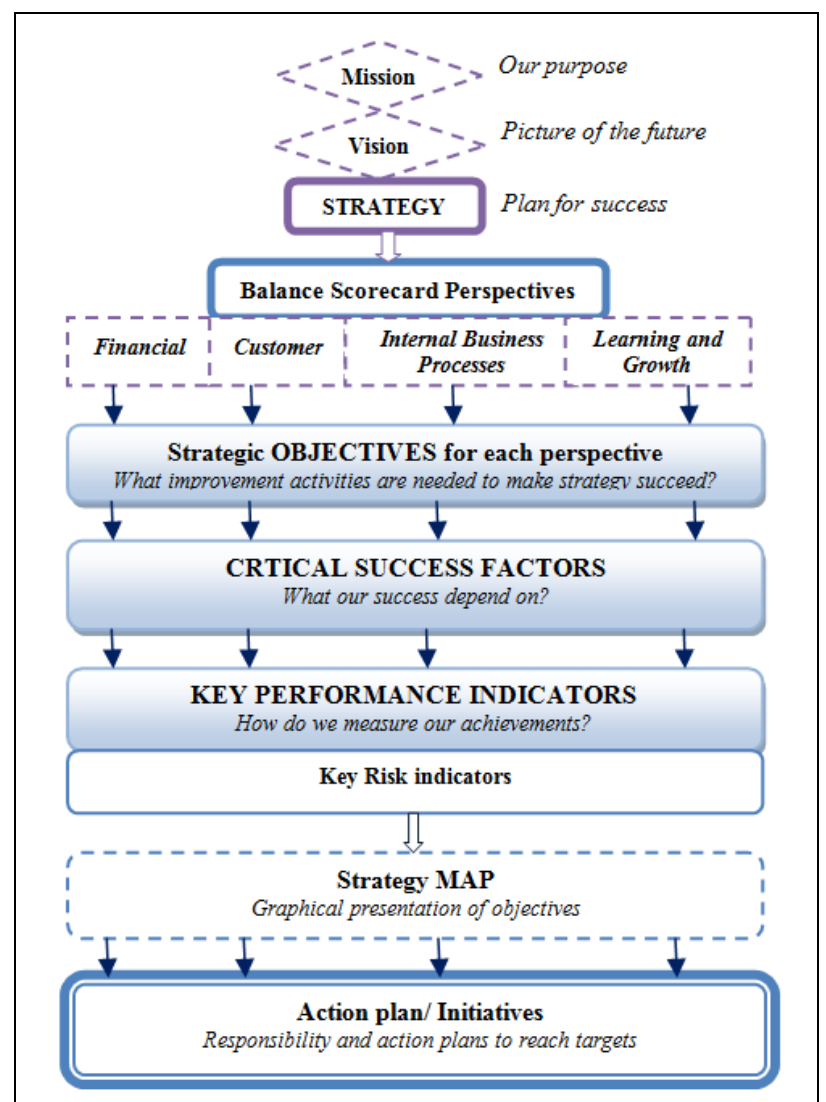

Fig. 2. A model of Balanced Scorecard

For each CSF, KPIs are identified to measure progress in achieving the objectives. For each KPI, targets and actions can be aligned and assigned to ensure activity is focused on delivering the objectives. Initiatives can be identified which will enable the targets to be achieved [10].
The Key Risk Indicators (KRIs) and KPIs can be made to work in direct collaboration with each other to facilitate business two different sides of the same coin. The KRIs provide an early warning signal to the management regarding the impending risks involved in a particular activity [11].

\subsection{Critical Success Factors}

CSFs are the parameters which are vital for the success of a project or success of a company. They monitor if a company or project achieve its mission.

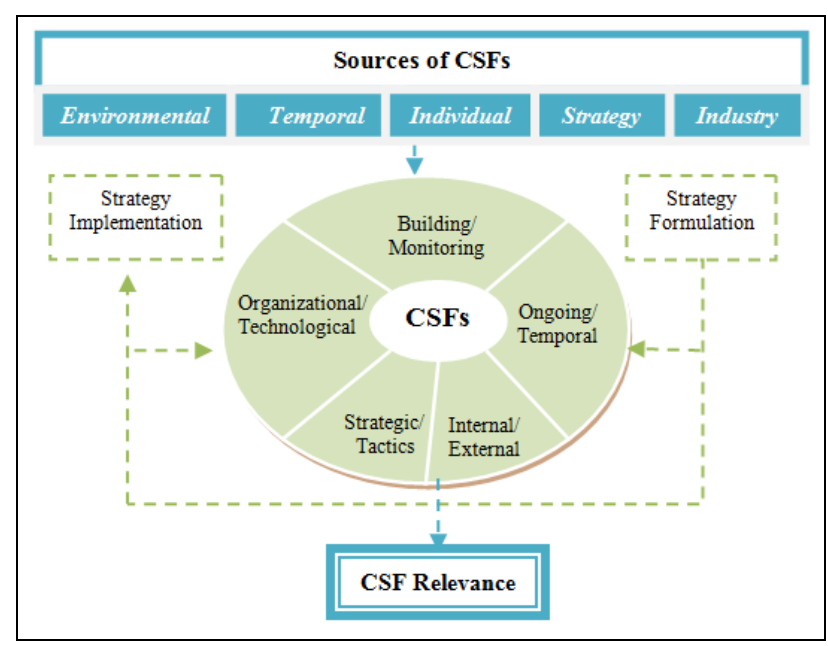

Fig. 3. Sources of CSFs [12]

The advantages of identifying CSFs are that they are simple to understand and they can be used in concert with strategic planning methodologies. Clarifying the priority order of CSFs, measuring results, and rewarding superior performance will improve the odds for longterm success as well [12].

\subsection{Key Performance Indicators}

Key Performance Indicators (KPIs) are measures that quantify objectives and reflect strategic performance and success of a company. The application of KPIs provides executives with a high-level, real-time view of the progress of a project or company [13].

\begin{tabular}{|c|c|}
\hline $\begin{array}{c}\text { Main groups of } \\
\text { KPIs }\end{array}$ & Description \\
\hline Leading & - financial indicators, measure past performance \\
\hline Lagging & $\begin{array}{c}\text { - typically non-financial indicators, measure } \\
\text { drivers for future performance }\end{array}$ \\
\hline Input & $\begin{array}{c}\text { - measure assets and resources invested in or used } \\
\text { to generate business results }\end{array}$ \\
\hline Process & $\begin{array}{c}\text { - measure the efficiency or productivity of a } \\
\text { business processes }\end{array}$ \\
\hline Output & $\begin{array}{c}\text { - measure the financial and nonfinancial results of } \\
\text { business activities. }\end{array}$ \\
\hline Actionable & - effect change \\
\hline Directional & - getting better or worse \\
\hline Qualitative & - a descriptive characteristic or an opinion \\
\hline Quantitative & - numerical values \\
\hline
\end{tabular}

Tab. 1. Main groups of KPIs [14]

Different types of quantitative indicators:

- Financial indicators (e.g. total costs in Eur);

- Numeric indicators (e.g. the number of customers);

- Percentage indicators (e.g. planned vs. actual);

- Comparative indicators (e.g. sales growth in comparison with the previous year); 
- End result or success indicators (e.g. number of satisfied customers, percentage of satisfaction).

Nowadays executives state revenue growth as their company's the most important priority and performance indicator, followed by customer satisfaction and increasing profitability.

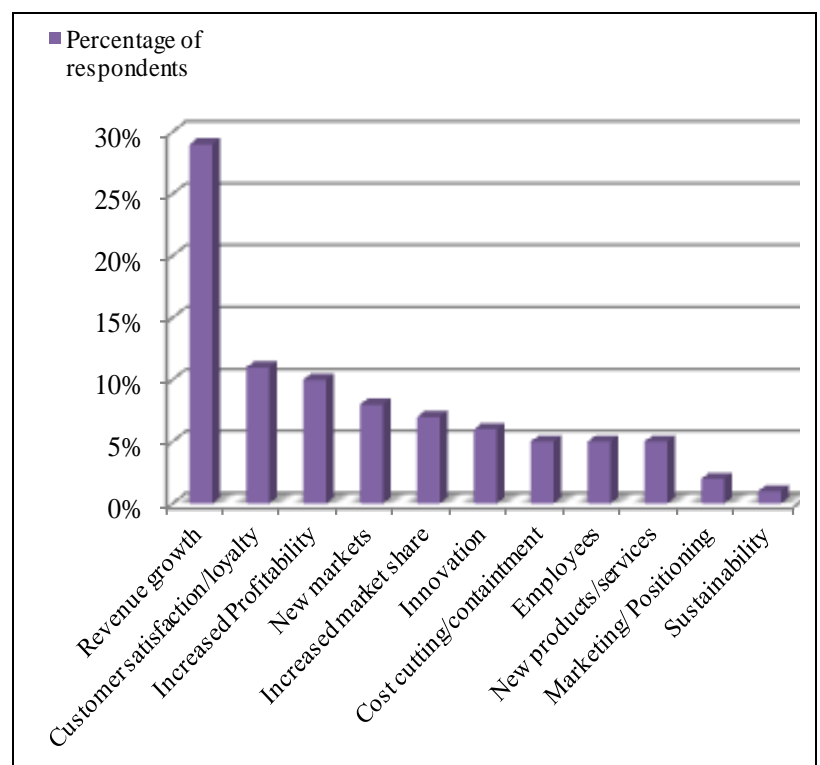

Fig. 4. Key priorities for executives [5]

Selecting and implementing effective CSFs and KPIs are very important for all the companies. Without good KPIs a company has no way to measure their performance in relation to their strategic goals [15].

\section{PRODUCT DEVELOPMENT PROCESS}

New product development is a business process in which a company develops new products, encompassing the process from original conception through manufacturing to finally market introduction [16].

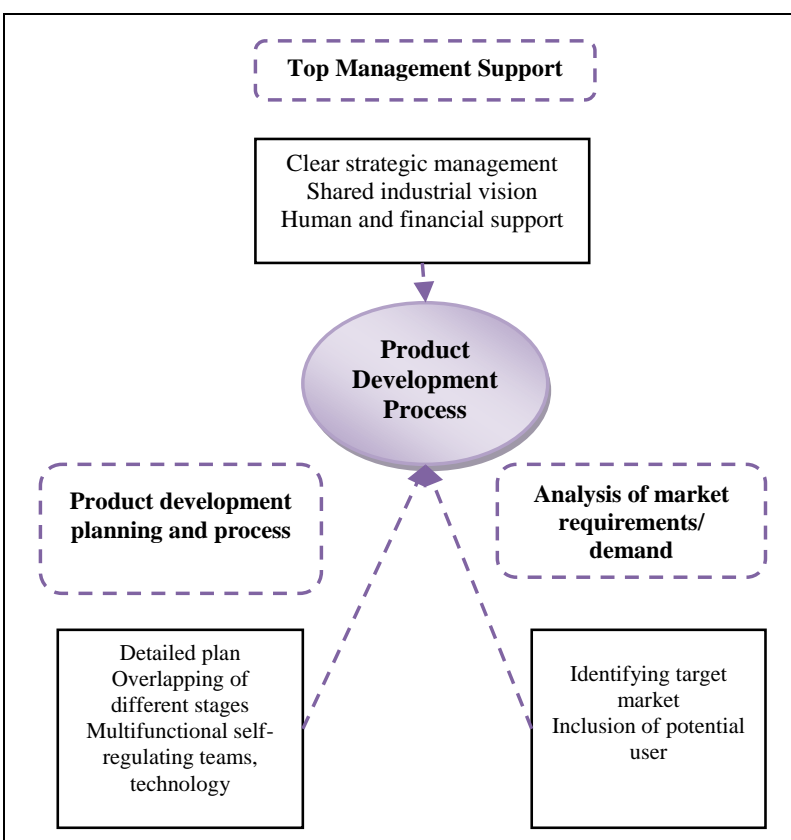

Fig. 5. A conceptual model for the CSFs of Product Development Process [16]
CSFs and KPIs vary from project to project focused on product development process. Findings indicate that the traditional indicators are no more applicable for measuring performance. This implies that the industry is slowly departing from the traditional quantitative performance measurement to a mix of both quantitative and qualitative KPIs of development projects.

It is essential to improve the product development process with the objective of reaching the market as quickly as possible. Companies have adopted new strategies and technologies to reduce the product development cycle time, taking into account various market and innovation barriers [17].

\section{CASE STUDY}

In next part we describe the company and its product development process as core process of analyzed company. Then we identify responsible role, CSFs and the associated KPIs that are compatible with most of its strategic objectives. We focus on the internal business processes and core competencies of employees in cooperation with the management of the company.

Meiren Engineering OÜ was founded in 2003. Since then team of engineers have been gathering experiences from various fields of mechanical engineering.

The company's primary fields of activity are engineering product research and development and sales of company products and project design services. They think that if machinery operates efficiently, it's also economical and environmentally friendly. The main product group they sell comprises large snowplows for highway use.

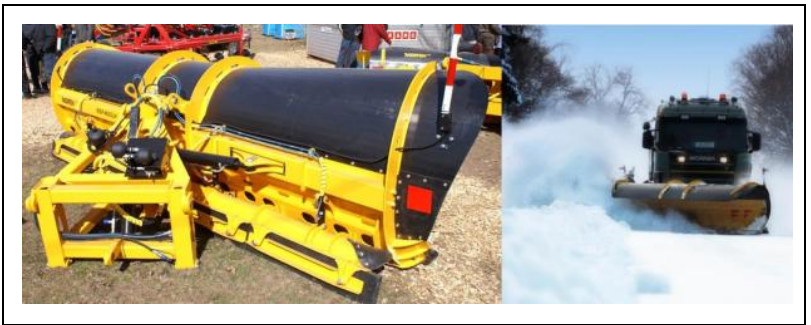

Fig. 6. Snowplow [18]

Their main skills are in the fields of hydraulic devices, conveyors, automated work lines, truck superstructures and moving mechanisms. Their scope covers 2D and 3D mechanical design, strength calculations, installation supervision on site, patent research, risk analyses, user and spare parts manual composition, CE-declarations [19].

\subsection{BSC implementation}

The implementation of BSC in Meiren Engineering OÜ is based on business performance evaluation. The approach starts from the company's mission, vision, goals and priorities - what it is trying to achieve in the long-term. 


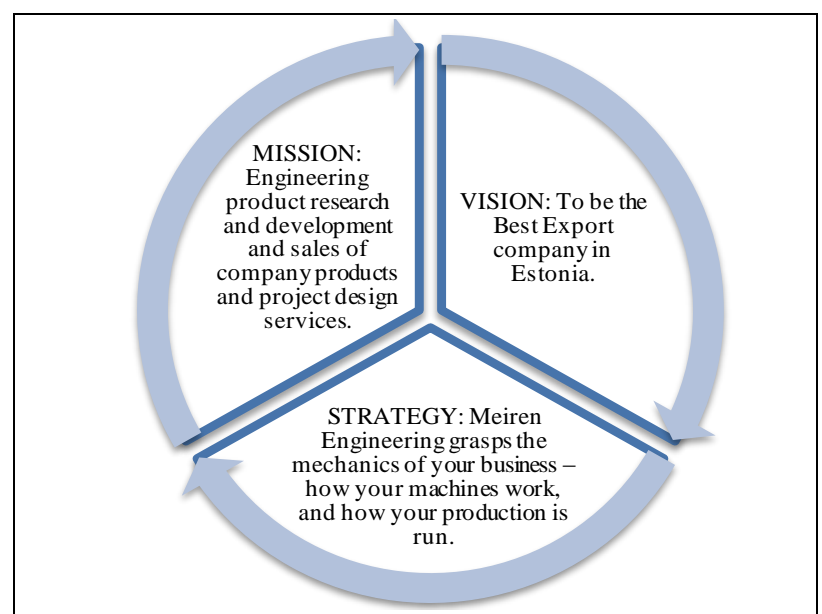

Fig. 7. Meiren Engineering OÜ’s mission, vision and strategy [19]

From there it moves to ensure that the CSFs and KPIs required to achieve these goals have been identified and planned for.
4.2 KPIs optimization for product development process with focus on the internal business processes perspective

Internal business processes perspective in Meiren Engineering OÜ is concerned with assessing the quality of people, processes and manufacturing so that product development process is making in the best way.

The key performance indicators of inner-business processes focus mainly on whether or not the company has established proper routine and managing mechanisms, and what inefficiencies still exist. It is important to describe how the data are collected depending on the actual result of the KPIs and optimize them. As to a project, the inner-business processes are mainly management activities at the beginning of product development process. Therefore, the indicators of these processes focus mainly on planning, machinery and manufacturing effectiveness, cost control, process and quality control and core competencies.

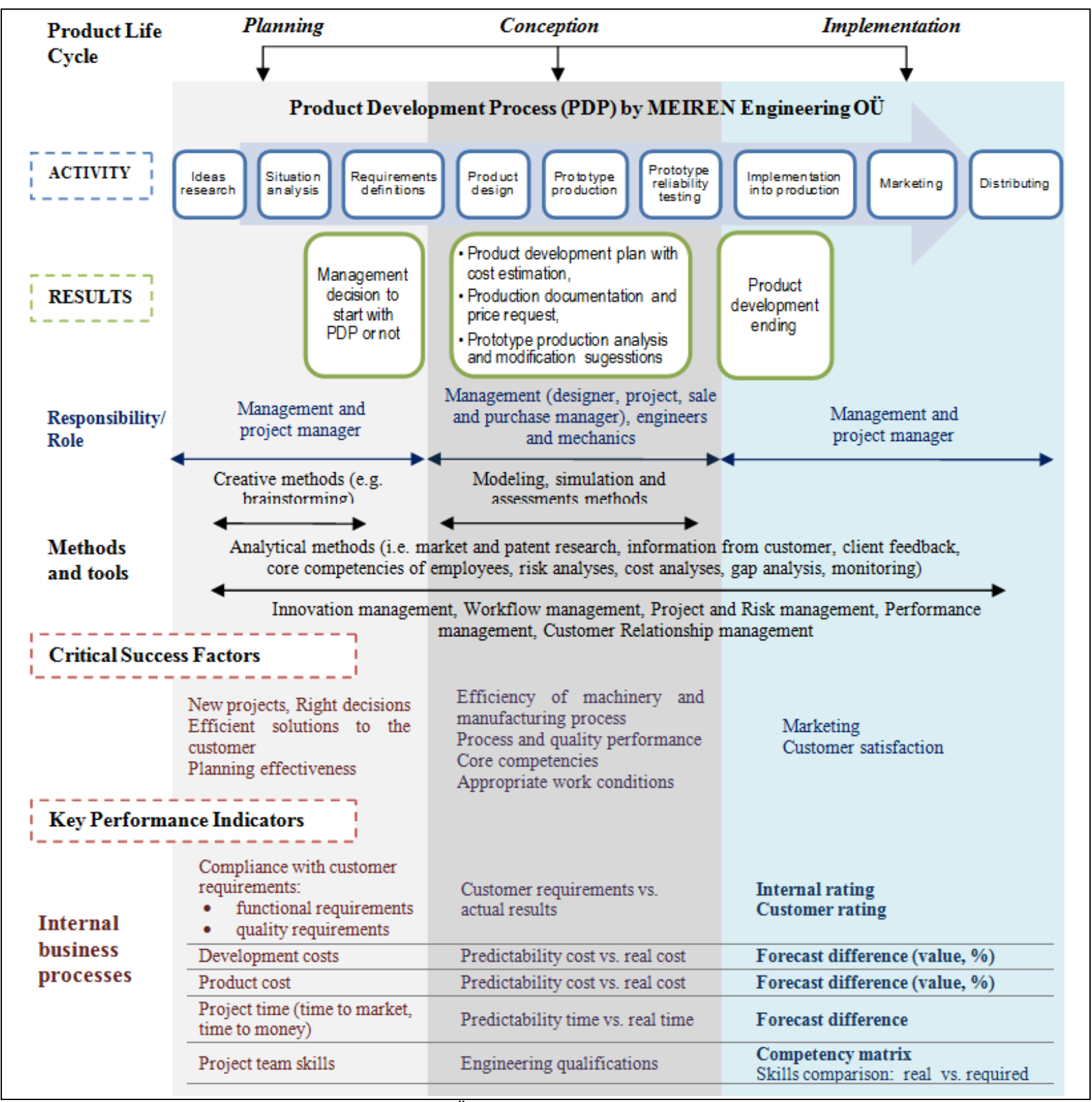

Fig. 8. Product development process by Meiren Engineering OÜ [19, 20] 


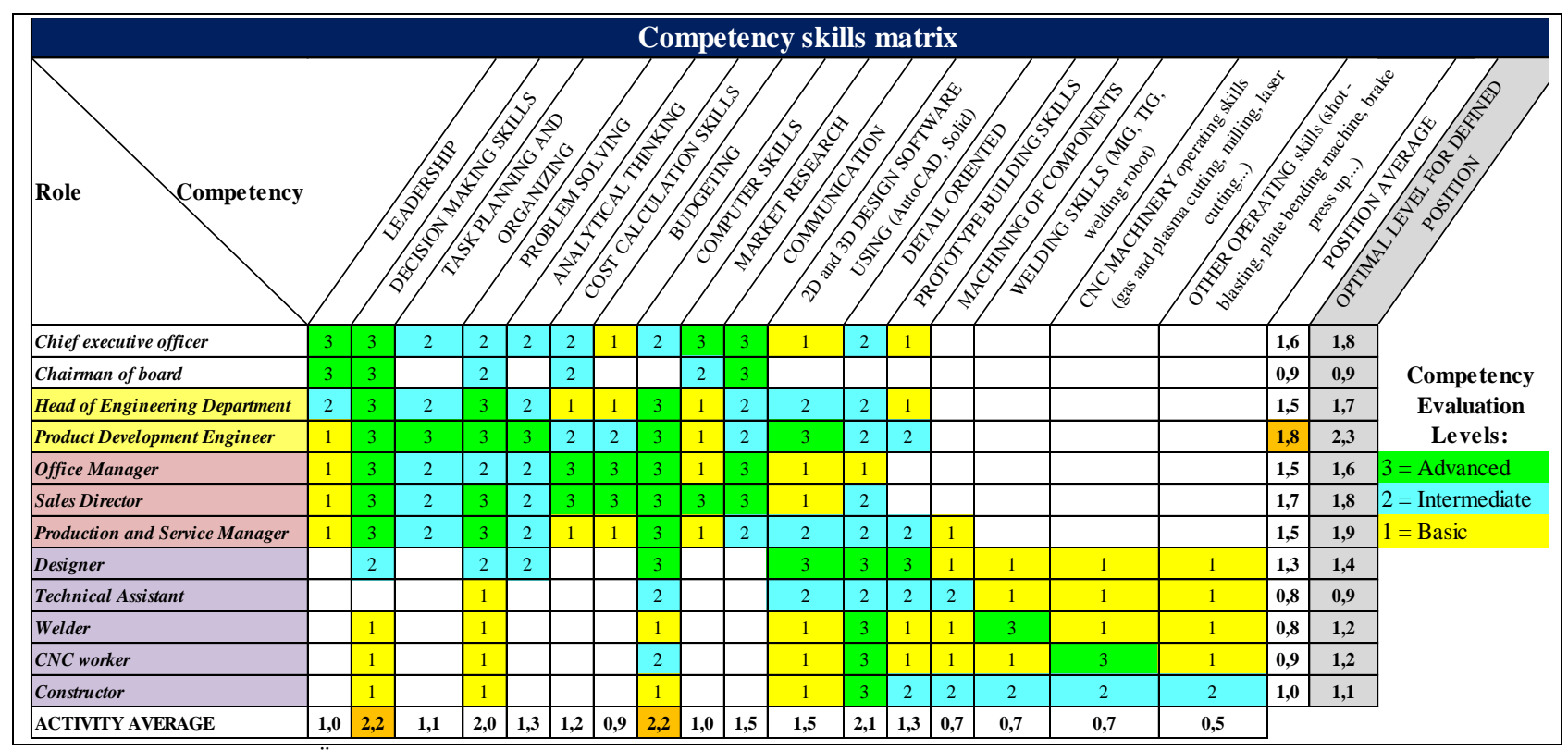

Fig. 9. Meiren Engineering OÜ competency matrix

\subsection{Core competencies}

Analyzed company believes that one of the most important success factors of BSC implementation is core competencies of its employees. BSC is not just the concept for top management, but mainly for project team and engineers.

After evaluating of Meiren Engineering OÜ employees in particular fields, follow competency matrix is constructed (see Fig. 9).

Competency matrix is a tool that compares the competencies of current or prospective employees with the competencies required to perform at an optimal level for a defined position.

Decision making and computer skills are the most advanced competencies in the company. Product development engineer reaches the highest position average, but nobody obtains optimal level of required skills. Company supports and offers skills training to improve workers capabilities.

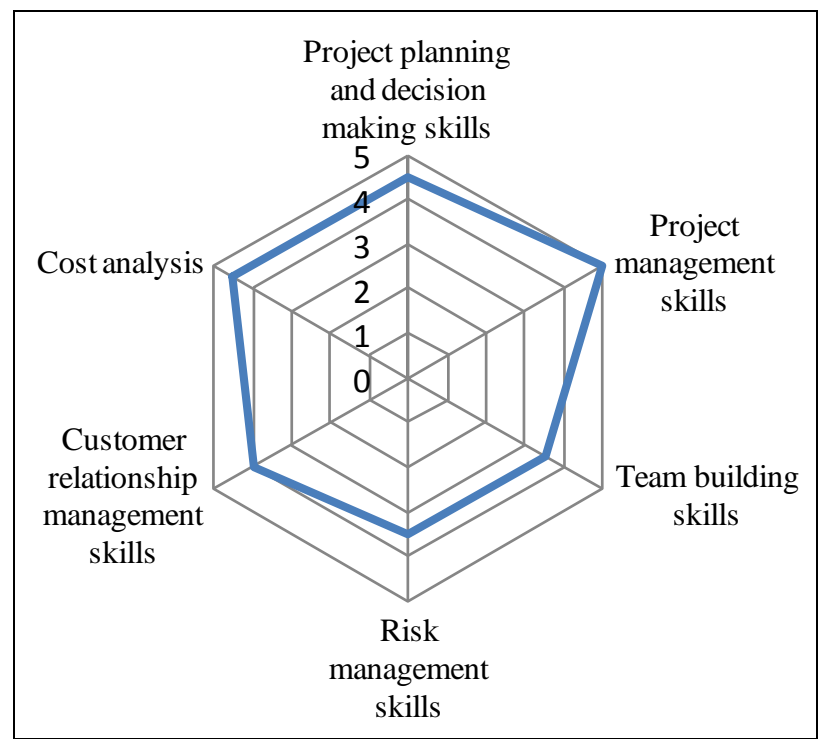

Fig. 10. Competency categories
To nurture the success of any project, a project team has to perform certain skills and understand the project development and management process. In Meiren Engineering OÜ, we tried to assess project team core competencies and skills as a whole. Core competencies are those capabilities that are critical to a company achieving competitive advantage.

The study was based on a qualitative approach, with interviews as the tool for data collection.

We rated various skills of project team members in six important competency categories:

1. Project planning and decision making skills,

2. Project management skills,

3. Team building skills,

4. Risk management skills,

5. Customer relationship management skills,

6. Cost analysis and management skills.

Evaluation scale was determined from 1 (lowest) - 5 (highest). The key core competencies for this company are mainly those that enable the creation of new products and services. Figure 10 represents results of survey.

Project team reached high level in each monitored. It has the best skills in the field of project planning and decision making and the worst (but always very good) in the field of project risk management.

But core competencies are not seen as being fixed in Meiren Engineering OÜ. They should change in response to changes in the company's environment. They are flexible and evolve over time. As a company evolves and adapts to new circumstances and opportunities, so its core competencies will have to adapt and change.

A competence which is central to the business's operations but which is not exceptional in some way should not be considered as a core competence, as it will not differentiate the company from any other similar 
companies. There are three possible tests for Core competencies:

a) Potential access to a wide variety of markets - the core competency must be capable of developing new products and services.

b) A core competency must make a significant contribution to the perceived benefits of the end product.

c) Core Competencies should be difficult for competitors to imitate. In many industries, such competencies are likely to be unique [21].

Senior management cannot focus on all activities of a business and the competencies required undertaking them. So the goal is for management to focus attention on competencies that really affect competitive advantage. Individual competence encompasses the knowledge, skills and abilities to deal with issues related to organizational, social and technological factors involved in projects.

\section{CONCLUSION}

Considering the characteristics of Balanced Scorecard perspectives, current paper establishes the product development evaluation system based on the critical success factors and key performance indicators. They vary from project to project focused on product development process. It is difficult to define, evaluate, measure and optimize success and performance of this engineering process. KPIs reflect the quality of the management activities and focus on progress, costs, time, performance, efficiency, customer satisfaction and internal communication and cooperation. Most of KPIs in analyzed company, included in internal business perspective, are based on estimating and comparing the real with planned results which show the quality of project team planning. Skills and knowledge of project team members and engineers are very important. Through the various projects their specific skills, competencies and needs are developing and they should aim to optimal level. Core competencies require continuous improvement and development. Developing core competencies needs a lot of time and resources.

\section{ACKNOWLEDGEMENTS}

This research was supported by Innovative Manufacturing Engineering Systems Competence Centre IMECC, co-financed by European Union Regional Development Fund (project EU30006).

\section{REFERENCES}

[1] Riives, J.; Karjust, K.; Küttner, R.; Lemmik, R.; Koov, K. \& Lavin, J. (2012). Software development platform for integrated manufacturing engineering system. Proceedings of the 8 th International Conference of DAAAM Baltic Industrial Engineering 19-21st April 2012, Tallinn, Estonia, ISBN: 9789949-23-265-9, pp. 555 - 560.

[2] Karjust, K.; Küttner, R. \& Pääsuke, K. (2010). Adaptive web based quotation generic module for SME's. Küttner, R. (Toim.). Proceedings of the 7th international conference of DAAAM Baltic industrial engineering, 22-24th april 2010, Tallinn, Estonia, pp. 375-380.
[3] Maverick Technologies. (2008). Key Performance Indicators (KPI): Visualization Tools for Lean Manufacturing Facilities. Available from:

http://www.mavtechglobal.com/shared/pdf/wp_KPI.pdf, Accessed on: $2012-05-20$

[4] Rigby, D. \& Bilodeau, B. (2011). Management Tools and Trends 2011. Available from:

http://www.loyaltyrules.com/management tools/Management To ols_and_Trends_2011_Final_Results.pdf, Accessed on: 2012-0401

[5] Rigby, D. \& Bilodeau, B. (2011). Management Tools \& Trends 2011 brief. Available from:

http://www.bain.com/Images/BAIN_BRIEF_Management_Tools. pdf, Accessed on: 2012-04-01

[6] Kaplan, R. \& Norton, D. (2007). Balanced Scorecard Strategický systém měreni výkonnosti podniku. Management Press, ISBN: 80-7261-177-5, Prague

[7] Niven, R. P. (2002). Balanced Scorecard: Step by step. John Wiley \& Sons, Inc., ISBN 0-471-07872-7, New York

[8] The measures of success: Developing a balanced scorecard to measure performance. (1998). Accounts Commission for Scotland, ISBN 0906-206-52-9. Available from:

http://www.evaluationsupportscotland.org.uk/downloads/balanced scorecard.pdf, Accessed on:: 2012-05-20

[9] Parmenter,D. (2009). Finding your organization's critical success factors. Available from: http://davidparmenter.com/files/findingyour-organisations-critical-success-factors-nov-09.pdf, Accessed on: 2012-05-25

[10] Bernard, M. (2010). How to Design Key Performance Indicators. The Advanced Performance Institute. BWMC Ltd. Available from: http://www.apinstitute.com/media/3970/how_to_design_key_performance_indic ators_indicators.pdf, Accessed on: 2012-05-30

[11] AKS-Labs. KRI (Key Risk Indicators) Toolkit. Available from: http://www.strategy2act.com/solutions/risk_metrics_excel.htm, Accessed on: 2012-05-30

[12] Esteves de Sousa, J.M. Definition and analysis of critical success factors for ERP implementation projects. Available from: http://jesteves.com/Tesis_phd_jesteves.pdf, Accessed on: 201205-31

[13] Wagner, J. (2009). Merění výkonnosti, Jak měrit, vyhodnocovat a využivat informace o podnikové výkonnosti. Grada Publishing, ISBN 978-80-247-2924-4, Prague

[14] Parmenter, D. (2008). Kličové ukazatele výkonnosti: Rozvíjení, implementováni a využiváni vítězných kličových ukazatelu výkonnosti. Česká společnost pro jakost, ISBN 978-80-02-020837, Prague

[15] McNeeney, A. (2005). Selecting the Right Key Performance Indicators. Available from: http://www.mtonline.com/component/content/article/103-april2005/639selecting-the-right-key-performanceindicators.html?directory $=90$, Accessed on: 2012-06-01

[16] March-Chorda, I; Gunasekaran, A. \& Lloria-Aramburo,B. (2002) Product development process in Spanish SMEs: an empirical research. Technovation 22, May 2002, ISSN: 0166-4972, pp. 301312, Elsevier Science Ltd. Available from: http://www.sciencedirect.com/science/article/pii/S016649720100 0219, Accessed on: 2012-06-03

[17] Hui, L. (2010). Building up a Performance Indicator System of International Projects, Based on the Balanced Scorecard. Management Science and Engineering, 2010, ISSN 1913-0341, pp. $82-91$. Available from:

http://www.cscanada.net/index.php/mse/article/view/j.mse.19130 35X20100402.007/1348, Accessed on: 2012-06-8

[18] Meiren Engineering OÜ: Available from: www.meiren.ee

[19] Internal material of Meiren Engineering OÜ

[20] Zalai, K.; Kalafutová, L.\& Šnircová, J. (2004). Finančnoekonomická analýza podniku. Sprint vfra, ISBN 80-88848-89-1, Bratislava

[21] Core Competencies. Available from: http://www.vectorstudy.com/management_theories/core_compete ncies.htm, Accessed on: 2012-07-20 